\title{
Indicators of Natural Resource Conflict in Farmer Communities in Kendeng Mountains Central Java
}

\author{
Hadi Suyono \\ Faculty of Psychology, Universitas Ahmad Dahlan \\ hatijernih06@gmail.com \\ (corresponding author) \\ Suryanto \\ Faculty of Psychology, Universitas Airlangga \\ suryanto@psikologi.unair.ac.id
}

\begin{abstract}
The aim of the study is to determine the indicators of natural resource conflicts in the farming communities in Kendeng Mountains who chose to focus on the reality of natural resource conflicts. This study uses a qualitative method with a phenomenological approach to uncover social experiences and gain meaning. Subjects were selected based on purposive sampling technique, respondents were determined according to the characteristics that had been previously chosen. Respondents were farmers who owned land in Kendeng Mountains region in Pati and Rembang Regency, Central Java. Respondents were farmers affected by mining natural resources in the form of karst. Furthermore, data is obtained using semi-structured interview techniques and analyzed using steps to proceed, prepare, and read data, do coding, write down settings, describe respondents, create categories, describe themes, present in narrative form, and interpret. Our findings show that indicators of natural resource conflict in the farming community in Kendeng Mountains are life threat, leader distrust, motivation, social capital, and social identity. A more detailed description of this research can be seen in the section below.
\end{abstract}

Keywords: Indicators of conflict, natural resources, farming communities

Received I5 September 2018/Accepted 29 November 2018 @ JEHCPAll rights reserved

\section{Introduction}

The study of natural resource conflicts has been carried out by experts in their fields. Various natural resources conflicts antecedents have found in the past studies. For example, Lindahl, Johansson, Zachrisson, \& Viklund, (2018) found the conflict in Sweden occured because of the rejection of mining exploitation in mountainous areas that threatened the sustainability of natural resources. In Talvivaara Finland, the conflict occurred and caused by the contamination of water as a result of natural mining resources from industry (Mononen, 
Tiainen, \& Sairinen, 2017). Singh and Narain (2017) found that the conflict in India is triggered by water resources management. In Naimina Enkiyo forest area Kenya, leadership has role in mobilizing local citizens in the involvement of natural resource management conflicts (Garcia, 2017). Abuya (2016) found that land ownership, unfair compensation, uneven resource distribution, environmental degradation, poverty, and human rights violations causes conflicts in titanium mining at Kwale Kenya.

Other studies use a social identity approach to explain the political and social conflict in environmental and natural resource management (Colvin, Witt, \& Lacey, 2015). The act of provocation by using natural resources on local ethnic identity triggers the dynamics of social conflict in Bolivia (Mahler \& Pierskala, 2015). Climate change and rainfall also lead to social conflicts in Africa such as demonstrations, riots, strikes, communal conflicts, and antigovernment violence (Hendrix \& Salehyan, 20I2). A study have conducted on natural resource conflicts by comparing between Indonesia with Malaysia (Herdiansyah, Soepandji, Seda, \& Dewi, 2014). Another study has resulted in the findings of the failure of environmental policies regarding land management which led to conflicts in Burkina Faso West Africa (Gray, 2002).

Various studies on natural resource conflicts that have been actualized in various countries are very important to be implemented in Indonesia. Scientific studies need to be carried out in Indonesia because it is prone to natural resource conflicts. Titian (20II) has conducted research showing that natural resources are included in the four major variances that causes conflict in Indonesia. One of the natural resource conflicts occurred in Kendeng Mountains, Central Java. Problems occur because Kendeng mountains are used as mining areas for karst. The karst is used as a raw material for producing cement. Citizens around the Kendeng Mountains reject karst mining due to the environmental damage it poses to the mountainous area.

Various researches have been conducted to explore natural resource conflicts in the region of Kendeng Mountains. Past study highlights the issue of Samin farmers who are against karst mining in Kendeng Mountains. Their refusal of karst mining in Kendeng Mountains is mainly because mining contradicts their basic belief in respecting the balance of nature. This belief 
will be disturbed by karst mining that would destroy the natural balance. For example, karst mining will prevent the mountain from being used as a source of water, floods would occur because the karst mountains can no longer function as rainwater infiltration, and ignite the extinction of flora and fauna (Azis, 20I2).

In addition to the study on the resistance of Samin community against karst miners, there is another study on social conflict regarding karst mining in Kendeng Mountains (Suharko, 2013). The study found that social conflict occurred between mining company and the farming community. Social conflicts occur due to conflicts using natural resources consisting of limestone, clay, and water. Social impacts developed after the karst mining policy. Village communities around the area are designated as karst mining area, resulting in discordance between citizens. Some citizens agree and some others oppose karst mining. These conditions lead to fading social harmonization as indicated by social interaction with mutual suspicion between relatives and neighbors.

Study on social conflict in the Kendeng Mountains is more comprehensive with the study of conflicts between indigenous people consisting of farmers and corporations from 2008 to the present. Conflict occurs because of a conflict of interest. Indigenous people consisting of farmers that have the principle that the karst mountains and ecosystems must be preserved. This preservation is driven by the interests of the Kendeng Mountains to save water resources. Adequate water resources provide an opportunity for indigenous peoples to continue farming, which is the only livelihood in the village. Contrary to company interests, optimal use of karst will benefit regional and national economic revenues (Suharko, 2016).

The different analysis of natural resource conflicts in Kendeng Mountains produces findings that the actors included in the conflict vortex consist of various parties carrying the burden of their respective interests. Actors involved in the conflict are pro-mining community organizations, contra-mining community organizations, non-governmental organizations, religious groups, companies, and academics (Oktaviana, 2016). The forms of conflict rejection of company are in vertical and horizontal conflict. Vertical conflict occurs between the community and investors. Horizontal conflicts occur between the people who were pro and contra of the plan (Firdaus, 20I5). 
The social movement rejecting karst mining is another focus of previous study that examines conflict in Kendeng Mountains. The results showed that the social movement against karst mining was motivated by the belief of the Samin people that the profession of being a farmer is a noble profession for preserving the environment. Belief embedded in each of the Samin people is manifested in the perspective of if the environment is damaged, then the order of the Samin people also becomes damaged. This perspective makes the Samin people try to maintain, care for, and preserves the environment. For the people of Samin, protecting earth is a vital responsibility. This is because the earth has the meaning of the mother who nurtures. The meaning of the mother who nurtures can be interpreted more broadly, if the people protect the environment, then the earth also protects the people. The teaching that moves the Samin people has the responsibility of maintaining land and water (Darmastuti, Bajari, Martodirdjo, \& Maryani, 2016).

The social movement related to preserve natural resources, includes women as the actor and main support on farmers' social movements against karst mining in Kendeng Mountains. Specifically the study of women's social movements in the vortex of conflict in natural resources of Kendeng Mountains discusses eco-feminism. The women's movement has a very central role in fighting the mining of karst in Kendeng Mountains. Women are in the front row of every action taken to protest the policy of exploitation of karst. In addition to being at the forefront of every action being held, women activists refusing karst mining become a leaders in driving the wheels of social movements against karst mines. Women became the coordinator of the social movement refusing the mining of karst in the villages of Kendeng Mountains. This association joins the Community Care Network for Kendeng Mountains in Rembang (JM-PPK Rembang). Women fight because karst mining has negative impacts. Karst mining results in difficulties in obtaining water resources. A rare source of water causes obstacles for female farmers to meet water needs, especially irrigating rice fields, managing livestock, and fulfilling their daily needs. Not only in the form of difficulties in getting clean water, but also a negative consequences on the production of agricultural products and health. Mining activities cause air pollution so that plants cannot thrive and people suffer from respiratory problems (Fitri \& Akbar, 2017). 
Previous study of environment-based policies and local related to natural resource conflicts in Kendeng Mountains has been conducted. Subarkah \& Wicaksono (2017) found that people of Sedulur Singkep's resist to the establishment of a cement plant in its area based on the empirical view of Kendeng Mountains having the benefit as a source of water capable of irrigating 15,879.9 hectares of agricultural land. Kendeng Mountains are also useful as a source of sustenance for people that using Kendeng Mountains land planted with intercropping various agricultural commodities.

Nurmeida, Purwoko, \& Setiyono (2017) found same conflict between corporate and community over the establishment of cement factories in the karst area of Sukolilo, Pati Regency. The results of the study indicate that conflict occurred because the establishment of cement factory took raw materials in the form of karst from Kendeng Mountains, damaging the environment. Environmental damage such as loss of water sources, air pollution threatens people's health, and noise can disrupt the peace of the people.

Based on several past studies, there are found that the studies examining natural resource conflicts is still limited, especially in exploring the dynamics of the conflict process in farming community (Suharko, 2013; Firdaus, 2015; Darmastuti, Bajari, Martodirjo, \& Maryani, 2016; Subarkah \& Wicaksono, 2017). Past studies that have been carried out have not explored the indicators that cause conflict (Suyono, 2013; Darmastuti, Bajari, Martodirjo, \& Maryani, 2016; Subarkah \& Wicaksono, 2017). The findings of the conflict indicator are useful as a basis for the early warning system (Suyono, 20I5), which is used to prevent conflicts from reaching the stage of escalating violent conflicts. This is what underlies this research intending to find indicators of conflict in the farming community caused by mining of natural resources in the form of karst.

\section{Method}

We used a qualitative research method, which emphasizes on the nature of reality that develops socially, focuses on situations that build investigations and looks for answers to questions derived from social experience to obtain meaning (Denzin \& Lincoln, 1994). A 
qualitative method was chosen according to the focus of the study emphasizing the reality of natural resource conflicts that developed in the farming community. The implementation of this qualitative method can be used to obtain answers from through social experience and obtain meanings by finding indicators of conflict.

Based on this, the phenomenology approach is used to reveal human consciousness regarding the object of experience actively. Phenomenology also explains the basic structure of reality, interpretatively focusing on the attention of meaning and experience (Denzin\& Lincoln, 1994). Based on Denzin \& Lincoln's (1994) view, the phenomenology approach was chosen because it enables us to explore farmers' awareness of experiences in conflict situations. Exploration of experience is interpreted by considering the meaning and experience of farmers in their involvement in natural resource conflicts phenomenon. The meaning and experience are actualized through indicators of conflict in the farming community of Kendeng Mountains.

Respondents were selected using a purposive sampling technique based on predetermined inclusive criteria, namely farmers who own land in Kendeng Mountains region in Pati and Rembang Regency, Central Java and affected by karst mining. Karst mining caused a water crisis resulting in drought in rice fields. This drought happened because Kendeng Mountains were no longer able to function to store water due to environmental damage as a result of karst mining. The factory uses karst as a raw material for making cement. This situation triggered the respondents to be involved in carrying out resistance movements to thwart karst mining. It causes farmers to experience conflicts with factories that carry out karst mining in Kendeng Mountains.

Data were obtained using a semi-structured interview technique. After the data was collected from respondents, a systematic analysis was carried out with the steps suggested by Creswell (2014), namely: processing and preparing data, data familiarization, coding, writing settings, describing respondents, creating categories, describing themes, presenting in narrative forms, and interpretations. 
The credibility of the research is achieved by conducting a validation strategy through triangulation. The triangulation is carried out by utilizing various theories, literature sources, expert views that are tailored to the theme, and other useful research to examine the truth and evidence to ensure validity.

\section{Result}

The result of the study shows that natural resource conflict in the farming community in Kendeng Mountains is caused by threats, distrust of leaders, motivation, social capital, and social identity. Further explanation of the result of the study is in the section below.

\section{Life Threat}

Based on interviews with respondents, conflicts occur because of the threats to environmental sustainability. Respondents revealed that environmental quality must be preserved. A well-maintained environment will be useful for human survival. Efforts are made to condition nature to be sustainable with hopes that the next generations can make good use of nature to fulfill their welfare. This was proven by the respondent's statement as follows:

"... so happy to be able to preserve nature. Life is about trying to preserve the environment as an inheritance for our children and grandchildren. If the land is taken by someone else ... then there will be nothing left for our children and grandchildren ..."

The hope to preserve the environment is different with reality. Respondents revealed that the efforts to preserve nature are threatened by corporations exploring karst as raw material for making cement. The impact of karst mining causes environmental damage. Reduction in biotic and biotic resources causes the ecosystem to lose its balance. The threat to environmental damage has encouraged farmers to fight. The movement rejecting karst mining triggered conflicts between farmers and corporations. This is shown in the farmers' statement as follows: 
"... karst mining from the factory will cause the water source to die. If the water source dies, plants will die, the animals in the mountains will also die, all kinds of animals and plants will become extinct ... this condition will disrupt the balance of nature ... this is the reason why farmers here fight miners and cement factories...."

Another finding revealed from the interview results is that the preservation of the earth is done to maintain their existence as farmers. Environmental sustainability is threatened with damage due to the presence of a cement factory that exploits karst in Kendeng Mountains. Karst damage can cause a threat to their profession as farmers that have been carried out for generations. The threat shows up because of the exploited karst in Kendeng Mountains resulted in the loss of water sources. The absence of these water sources causes farmers to lose their jobs because the only skill they have is farming. Livelihoods are lost due to dry water sources preventing crops from growing. This is shown in the respondent's statement as follows:

"....we might not work as farmers... the destruction of Kendeng mountains causes a loss of water resources ... there is no water source ... we cannot plant ... being a farmer has become our job through generations... we can't work anywhere else ... because we can only farm ... "

\section{Distrust towards leaders}

Another indicator revealed through the interview is the distrust that respondents have towards leaders. A statement from the respondent indicated that there had been mistrust towards the leader. This is because the leader seems wealthy but is still greedy to gain more. The life of the famer community and the officials are like the world of puppets, namely the story of Pandawa and Kurawa. The Pandawa figure is farmers, who have honesty but are removed by greedy leaders such as Kurawa. 
"... those who become officials are already rich ... but they're greedy to gain more wealth ... they keep on taking what is supposed to belong to us ... they are like Kurawa ... greedy leaders ... we are like Pandawa, who has honesty ... "

Statements from respondents also indicate that there are mistrust in people who are considered smart. Those smart people refer to leaders. This distrust occurs because people assumed that smart people only made promises and did nothing to keep those promises. The promises given by many leaders are not in accordance with reality. There are plenty of smart people behave in cruel and irresponsible ways. The promise they gave was merely rhetoric to maintain power, not for the welfare of society. This is shown by the respondent's statement as follows:

"... they are smart people ... smart people who have lots of promises ... promises that they never keep ... so different than reality ... some of them are even cruel and irresponsible ... they only think about power ... only think about themselves ... never think about people's welfare ... "

Farmer's distrust is reinforced by the respondent's statement with a caution to interact with leaders. That caution is based on the fact that there are leaders acting as colonials. The colonials did not come from other countries, but they were among our friends.

"... there are leaders who are like colonials ... not from other nations ... but from fellow nationals ... we must be vigilant and careful with them ..."

\section{Motivation}

Statements from the respondents also explained the motivation that caused farmers to make a resistance movement against karst mining. The struggle for karst mining has caused land conflicts because of the need to maintain land. The underlying need for maintaining land is based on the motivation for the survival of future generations. This motivation moves farmers to struggle selflessly to maintain Kendeng Mountains not to be used as a mining 
area. The selfless continuous struggle aimed at preserving of Samin community as farmers. This is shown by the statement from the respondent as follows:

"... the struggle that we are doing is for future generations as farmers ... so that our descendants can farm and depend their lives on the land ... if the land is damaged ... then we obviously cannot farm ..... our children ... our grandchildren ... we won't be able to live ... we sincerely fight because we want to be farmers for generations ... "

Other data shows that the impact of karst mining in Kendeng Mountains is the loss of food resources to farmers. This happens because the scarcity of water sources due to karst mining makes farmers unable to plant crops anymore. The absence of agricultural activities caused land become unable to produce food.

"... the Kendeng Mountains are ruined ... the source of water is gone ... and we can't plant ... if we can't plant, we can't eat ..."

Another process that makes Samin community have the urge to maintain their land is the fulfillment of the need to achieve welfare not only because of abundant wealth, but the wellbeing that they have can be fulfilled health, the ability to grow crops, the thriving of plants, and availability of food.

"We consider prosperous as healthy ... we can plant ... fertile plants ... and food is available ... it doesn't have to be abundance of wealth..."

\section{Social capital}

Social capital is the next indicator that makes farmers have the courage to defend the land. Social capital in the form of harmony and mutual support of fellow members is a force to fight karst mining. Another finding related to social capital is the struggle in rejecting karst mining in Kendeng Mountains is caused by the responsibility of caring for the surrounding 
environment. The responsibility made it possible for the farmers to struggleselflessly, not even expecting any wages.

"... we are getting along well ... whatever the case, we support and help each other ... we fight sincerely ... not intending to get anything else... our goal is to take care of Kendeng Mountains as water source ... so we can continue farming ... "

Social capital is manifested in intimate relationships, growing relationships that are closely based on emotional attachments between members of one community and other communities. This intimate relationship occurs because of the mutuality between members as an inseparable unity and the growing of a shared commitment to help each other. This process has made farmers grow to care for each other so that they have the power to fight corporations that do mining in the karst mountains.

\footnotetext{
"We care for each other ... we are like a big family ... if our family becomes one ... we love each other ... because this makes us strong to fight ..."
}

\section{Social identity}

Social identity is also an important indicator of this conflict. Social identity is reflected in the statement of the subject above, which states that farmers are a community that has honesty and can be trusted by other parties. Words always show something direct and clear. The farmer community members will convey words according to their mind and heart. This is what distinguishes farmer communities from other groups.

"... what makes us different is that ... we are honest ... our words are worthy of trust ... we speak for who we are ... because what we say is clear ... according to our heart and mind ... that's why we can act assertively..." 


\section{Discussion}

Based on the findings above five indicators have been found namely; threats, distrust of leaders, motivation, social capital, and social identity. The first indicator is threat, it is an essential indicator in natural resource conflicts in the farming community in Kendeng Mountains, it can be analyzed from the results of research conducted by Zarate, Garcia, Garza, \& Hitlan (2018) which explains cultural threat. This cultural threat is related to moral differences, norms, and values. Opinions from these experts can act as theoretical evidence that conflict occurs because there are different moral values between farmers and mining companies. Morally, farmers maintain the quality of the environment with the aim of ensuring that future generations can use nature to fulfill life. Meanwhile, companies do not think about morality. Companies, in the name of economic interests, destroy nature by carrying out karst mining regardless of future generations. To preserve the environment, some norms are run by farmers by caring for the environment as well as possible. Farmers do this by keeping Kendeng Mountains untouched by various parties for economic interests that have an impact on environmental damage. Concerning this norm, it becomes a problem when companies violate the norm, namely mining operations that damage nature. These differences in norms make farmers resist the mining company.

Values are an essential part of cultural threats. Its implementation is that a farmer is a noble profession because it provides benefits for life. Agricultural products can meet the basic needs of the community. This stimulates continuation to work as a farmer. The need to maintain the existence of being a farmer is threatened because of the karst mining in Kendeng Mountains causes a loss of water resources so that agricultural land becomes dry and cannot be planted again.

Threats that can cause conflict can be based on a meta-analytic review conducted by Riek, Mania, \& Gaertner (2006). Those experts explained that there are types of threat, one of them is a real threat which caused conflict. Realistic group conflict theory can be used as a basis to explain the occurrence of conflict due to risks that are realistic. Realistic group conflict theory reveals that two parties are competing for limited resources. As a result of the existence of a limited source, it impacts on threats from one party to another or vice versa. 
This happened in the conflict between farmers and companies in Kendeng Mountains. Farmers want to maintain a limited source of karst to conserve water availability. They have different interests with companies, which exploit karst as raw material for cement. Mining conducted by the company is a threat to the farming community to lose water sources as necessities to grow crops. The threat is moving farmers to refuse karst mining because dry land can cause job losses as a result of the absence of water sources. The process created a conflict with the company.

Specifically, environmental changes which also pose a threat that causes conflict has been reviewed by Brown, Hammal, \& McLeman (2007) arguing that climate change impacts on ecosystem damage such as loss of water sources. The study shows that the absence of water sources poses a threat to security disturbances that lead to conflict in Africa. Sims \& Saarinen (1989) also conducted typical research on environmental damage as a threat to farmers. The danger that occurs is ecological damage, making farmers unable to do proper planning in working on the agricultural land. This threat causes conflict. Previous studies have confirmed many evidences of research findings that the threat indicator have the potential to cause conflict (Maoz \& McCauley, 2008; Nash, McGregor, \& Prentice, 20II; Fritsche, Jonas, \& Kessler, 20II; Kamans, Otten, \& Gordijn, 20I0; Billiet, Meuleman, \& Witte, 20I4).

Subsequent analysis of the findings shows that natural resource conflicts in the farming community in Kendeng Mountains due to leader distrust (Keyton \& Smith, 2009). Those experts mentioned the dimensions that affect a leader's distrust are integrity, commitment, honesty, fulfillment of the promise, and fairness. Based on Keyton \& Smith (2009), indicators of leader's distrust that lead to conflicts over natural resources in farmer communities can be seen in leaders who have no integrity and commitment to make better lives for farmers. The leaders do not give their all and do not care about the fate of farmers who do not entirely have adequate welfare. In this condition, the leader does not care about the life of the farmer. Things that are done are the contrary, continuing to accumulate wealth for personal gain. 
Distrust of farmers is also due to the dishonesty of leaders. The farmer describes it as the puppet world that the leader is Kurawa, symbolized psychologically as a greedy, deceptive, and has a way that is not by moral values to achieve goals. Unlike the case with the farmers who are like Pandawa, positioned as a polite person, holding moral values, and idealistic in attaining goals. The philosophical values described through this puppet have led to the resistance of the farmers because the leader has no honesty in using his power.

Furthermore, distrust is caused by the inability of leaders to fulfill promises and act justly. This can be demonstrated by farmers who reveal that the leader is merely indulging in the promises he says and not living up to his words. Even leaders who are considered smart people do not act fairly by acting cruelly, irresponsibly, and working as colonials to maintain power.

Other findings to amplify the results of the study relating to indicators of leader's distrust stem from Jones, Wiley, LoPilato, and Dahling study (2018) which states that distrust of leaders depends on their actions following procedures, acting fairly on their members, and struggling for groups. The results of this study become a reference to explain the conflict of natural resources in Kendeng Mountains. Based on the statement of farmers that leaders should protect the people, when in fact they behave like colonials. The consequences that can be generated from the behavior of leaders as colonials are that they do not fight for the interests of farmers, but fight for their groups. This action makes the leader acts unfairly to the community including farmers.

Analysis related to motivation can be explained from the views of Miller, Goyal, and Wice (2017) that motivation develops in individuals because it responds to the needs of group members. Another thing that can be explained from the concepts of Miller, Goyal, and Wice (2017) is internalized motivation in a person because it fulfills the social expectations of the community. The theoretical foundation of the experts in this study can be used to explain that motivation grows because it responds to the need to defend the land from environmental damage caused by karst mining. 
Another thing that can be expressed is the motivation develops in farmers to meet the social expectations of children and grandchildren. For farmers, the sustainability of land must be maintained for the survival of future generations. Environmental sustainability needs to be kept because the natural damage caused by karst miners will result in future generations not having a livelihood. The predecessor generation and parents inherited farming skills to gain income. This reality makes Kendeng Mountains unable to be a source of water, so future generations can no longer farm because of dry land. This condition can cause the generation to lose their jobs because they cannot plant. The impact that can occur in the future of the farming community is experiencing poverty. This psychological situation is what drives farmers against karst miners that cause damage to Kendeng Mountains. That resistance creates conflict.

The motivation that causes conflict in the farming community in Kendeng Mountains can be based on the opinions of Schmidt, Palminteri, Lafargu, and Pessiglione (2010), it is because of the existence of incentives. Opinions from Reiss (2012) explain the intrinsic factors that lead to the development of motivation in a person. In addition to this, Maddox and Markman (2010) have suggestions that motivation is present because of the need to move someone to take specific actions. Jones and Jones (2013) add that motivation is caused by the existence of internal processes that are stimulated from the outside which make negative feelings arise.

The research perspectives and results from those experts can be explained that the motivation to become energy conflicts is caused by the intrinsic factor of maintaining the sustainability of Kendeng Mountains from karst exploitation by miners because farmers do not want to lose food sources. The need for food sources can't be fulfilled if the land cannot be planted caused by the absence of water sources as a result of environmental damage to Kendeng Mountains. This creates resistance because of the negative feelings stimulated from the outside, namely miners who are considered the main actors who damage the environment of Kendeng Mountains.

The next indicator of natural resource conflict in Kendeng Mountains is social capital. Social capital built in the farming community creates mutual support between one farmer and 
another to refuse karst mining. This resistance is part of responsibility and selfless struggle to maintain environmental sustainability. It is caused by the emotional attachment between farmers to build a shared commitment to prevent damage to Kendeng Mountains.

The theoretical concept can explain that finding social capital can develop because it comes from forces that grow from below in the local area by emphasizing one social unit on good intentions, friendships, and social relations between individuals into one family unit. This process makes the community a network that provides benefits, beliefs, perceptions of satisfaction, support, cooperation, and mutual interest among members. The established system is based on the underlying dimensions of altruism: structural (e.g., presence of actors, natural ties, resources), relational (e.g., trust, norms, reciprocal obligations, development of identity through interaction), cognitive (e.g., sharing of values, vision, strength of cognitive cohesion among members) (Forrest \& Kearns, 200I; Osgood \& Ong, 200 I; Carpenter, Daniere, \& Takahashi, 2004; Radnitz, Wheatly, \& Zurcher, 2009; Bhuiyan, 20I I; Cook, 2005; Herrero, 20I8).

Social identity is a part of the indicator that causes natural resource conflicts in Kendeng Mountains. Farmers identify themselves as a unique group, as a community that seeks honesty, trustworthiness, firmness, and convey messages to others according to their hearts and minds. Social identity is formed under the concepts of Tajfel and Turner (2004) suggesting that social identity is established through evaluations of oneself and other members that result in the community being unique as a group and different from outside groups.

The unique quality that distinguishes the group from out-groups is formed due to the categorization process that causes favoritism in the group. This process can lead to competition, resulting in the presence of in-group bias. This bias is shown by the perspective of seeing the group as better compared to other groups. This condition causes resistance against miners because miners are considered as an outside group that is not in accordance with the uniqueness of the group. Evidence of research shows that social identity causes conflict is originated from Kelman (2005), O'brien (1993), and Funk (2013). 


\section{Conclusion}

Based on the findings, we conclude that the indicators of conflict of natural resources among farmer community in Kendeng Mountain are: threats to environmental sustainability, distrust towards leaders, motivations that cause farmers to carry out resistance movements, social capital as the responsibility of preserving nature is formed because of the emotional attachment and commitment to help, and social identity as the uniqueness of the group as a result of self-evaluation of honesty, worthy of trust, that shows assertion.

\section{Acknowledgement}

This research has received a grant from the Ahmad Dahlan University Institute of Research and Community Service number PF-052 / SP3 / LPPM-UAD / VI / 2018. The author would like to thank the Chancellor of Ahmad Dahlan University Yogyakarta for the completion of this research.

\section{References}

Abuya, O., W. (2016). Mining conflict and corporate social responbility: Titanium mining in Kwale, Kenya. The Extractive Industries and Society, 3(2), 485-493.

Azis, M. (20/2). Identitas kaum Samin pasca kolonia pergulatan negara, agama, dan adat dalam pro-kontra pembangunan pabrik semen di Sukolilo, Pati, Jawa Tengah. (Postcolonia Samin identity of state, religion and custom in the pros and cons of building a cement factory in Sukolilo, Pati, Central Java) Kawistara, 2(3), 225-328. Retrieved from http://jurnal.ugm.ac.id/demilau/article/view/3927/3218.

Bhuiyan, H., S. (20II). Social capital and community development: A analysis of two cases from India dan Bangladesh. Journal of Asian and African Studies, 46(6), 533-545.

Billiet, J., Meuleman, B., \& Witte, D., H. (20/4). The relationship between threat and economic insecurity in times of economic crisis: analysis of european social survey data. Miggration studies, 2(2), 135-16I.

Brown, O., Hammal, A., \& McLeman, R. (2007). Climate change as the "new" security threat: implications for Africa. International Affair, 83(6), I I4I-I I 54. 
Carpenter, P., J., Daniere, G., A., \& Takahashi, M., T. (2004). Social capital and trust in South-East Asian cities. Urban Studies, 4I(4), 853-874.

Colvin, R., M., Witt, B., \& Lacey, J. (2015). The social identity approach to understanding socio-political conflict in enviromental and natural resources management. Global Environmental Change, 34, 237-246.

Cook, S., K. (2005). Networks, norms, and trust: the social psychology of social capital*2004 Cooley mead award adrees. Social Psychology Quarterly, 68(I), 4-I4.

Creswell, W., J. (20I4). Research design qualitatif, quantitative, and mix methods approaches. Fourth Edition.Thousand Oaks, California: Sage Publication Inc.

Damarstuti, R., Bajari, A., Atwar, B., Martodirdjo, S., H., \& Maryani, E. (2016). Gethok tular: Pola komunikasi gerakan sosial berbasis kearifan lokal masyarakat Samin di Sukolilo. (Gethok tular: The communication pattern of social movement based on local wisdom Samin people in Sukolilo.). Jurnal ASPIKOM, 3(I), I04-II8.

Denzin, K., N. \& Lincoln, S., Y. (1994). Handbook of qualitative research. California: Sage Publications.

Firdaus, T, S, M. (20I5). Konflik lahan pabrik semen oleh PT SMS di Kecamatan Tambak Romo, Kabupaten Pati. (Conflict of cement plant land by PT SMS in Tambak Romo District, Pati District). Naskah Publikasi. Retrieved from http://repository.umy.ac.id.

Fitri., I., A., \& Akbar. (20I7). Gerakan Sosial perempuan ekofeminisme di pegunungan Kendeng Provinsi Jawa Tengah melawan pembangunan tambang semen. (The ecofeminism women's social movement in the Kendeng mountains of Central Java Province fights the construction of cement mines). Comogov, 3(I), 75-8I.

Forrest, R., \& Kearns, A. (200I). Social cohesion, social capital, and the neighbourhood. Urban Studies, 38(I2), 2I25-2I43.

Fritsche, I., Jonas, E., \& Kessler, T. (20II). Collective reactions to threat: implications for intergroup conflict and of solving societal crises. Social Issues and Policy Review, 5(I), I0I-I36.

Funk, J. (2013). Toward an identity theory of peace building. CRPD Working Paper, I5.

Garcia, K., A. (2017). Exploring the "layeredness" of recurring natural resource conflicts: the role of Loita Maasai leadership in the Naimina Enkiyo Forest conflicts in Kenya. Land Use Policy, 65, 66-77.

Gray, C., L. (2002). Enviromental policy, land rights, and conflict: rethinking community natural resource management programs in Furkino Faso. Enviroment and Planning D: Society and Space, 20, 167-182. 
Hendrix, S., C., \& Salehyan, I. (20/2). Climate change, rainfall, and social conflict in Africa. Journal of Peace Research, 49(I), 35-50.

Herdiansyah, H., Soepandji, S., B., Seda, S., F., dan Dewi, (20I4). Conflict management of renewable natural resources in the border of Indonesia-Malaysia: sustainable enviromental approach. Procodia Enviromental Sciences, 20, 444-450.

Herrero, I. (2018). How family is family social capital ? Analyzing bonding social capital ? Analyzing bonding social capital in family and nonfamily firms. Family business review, I19.

ITP. (20I I). Dinamika konflik dan kekerasan di Indonesia. (Dynamics of conflict and violence in Indonesia). Jakarta: Yayasan Titian Perdamaian.

Jones, H., E., Jones, H., C., \& Price, F., H. (20I3). What is approach motivation ? Emotion Review, 5(3), 29I-295.

Jones, R., B., Wiley, S., LoPilato, C., A., \& Dahling, J., J. (2018). One of us ? How leaders can use subtle identity performance to build trust among ingroups and outgroups. Group Processes \& Intergroup Relations. I-I8.

Kamans, E., Otten, S., \& Gordjin, H., E. (20I0). Power and threat in intergroup conflict: how emotional and behavioral responses depend on amount and content of threat. Group Processes \& Intergroup Relations, I4(3), 293-310.

Kelman, C., H. (20I0). Conflict resolution and reconciliation: A social psychological perspective on ending violent conflict between identity groups: Landscape of violence an interdisciplinary. Journal Devoted to the Study of Violence, Conflict, and Trauma, I(I), article 5, I-9.

Keyton, J., \& Smith, L., F. (2009). Distrust in leaders. dimension, patterns, and emotional intensity. Journal of Leadership \& Organizational Studies, I4(I), 6-18.

Lindahl, B., K., Johansson, A., Zachrisson, A., \& Viklund R. (20I8). Competing pathways to sustainability? exploring conflicts over mine establishments mountain region. Journal of Enviromental Management, 218, 402-4I5.

Maddox, T., W., \& Markman, B., A. (2010). The motivation-Cognition, intrerface in learning and decision making. Current Direction in Psychological Science, 19(2), I06-I I0.

Mahler, A, \& Pierskalla, H., J. (2015). Indigenous identity, natural resources, and contentious politics in Bolivia: A Disaggregated conflict analysis, 2000-20II. Comparative Political Studies, 48(3), 30I-332.

Maoz, I,. \& McCauley, C. (2008). Threat, dehumanization, and support for retaliatory aggressive policies in asymmetric conflict. Jurnal of Conflict Resolution, 52(I), 93-I I6. 
Miller, G., J., Goyal, N., \& Wice, M. (2017). A cultural psychology agency: Morality, motivation, and reciprocity. Perspective on Psychological Science, I2(5), 867-875.

Mononen, T., Tiainen, H., \& Sairinen, R. (2017). Talvivaara mine and water pollution: an analysis of mining confict in Finland. The Extractive Industries and Society, 4(3), 640-65I.

Nash, K., McGregor, I., \& Prentice, M. (20I I). Threat and defense as goal regulation: from implicit goal conflict to anxious uncertainty, reactive approach motivation, and ideological extremism. Journal of Personality and Social Psychology, I0I(6), I29I-I30 I.

Nurmeida, A., Purwoko, \& Setiyono, B. (2017). Konflik Corporate vs Society: AnalisisterhadapKonflikdalamKasusPendirianPabrik Semen di Kecamatan Sukolilo, KabupatenPati. (Corporate conflict vs society: Analystship on the conflicts in the census of cement industry in Sukolilo Subdistrict, Kabupaten Pati.). Publication Manuscript. Retrieved October 16, 2016, from http://ejournal.undip.ac.id/index.php/ipgs/article/view/240I/2406.

O'brien, J. (1993). Ethnicity, national identity, and social conflict. Nordic Journal of African Studies 2 (2),60-80.

Oktaviana, G. (20I5). Analisis konflik sumber daya alam di Pegunungan Kendeng Utara, Kabupaten Pati, Provinsi Jawa Tengah. (Analysis of natural resources conflicts in the Kendeng North Mountains, Pati District, Central Java Province). Unpublished undergraduate thesis. Bandung: Departemen Komunikasi dan Pengembangan Masyarakat Fakultas Ekologi Manusia Institut Pertanian Bogor.

Osgood, M., \& Ong, N., B. (200I). Social capital formation and development in marginal communities, with reference to post-Soviet societies. Progress in Development Studies I(3), 205-2I9.

Radnitz, S., Wheatly, J., \& Zurcher, C. (2009). The origins of social capital. Evidence from a survey of Post-Soviet Central Asia. Comparative political studies, 42(6), 707-732.

Reiss, S. (20I2). Instrinsic and extrinsic motivation. Teaching of Psychology, 39(2), I52-I 56.

Riek, M., B., Mania, W., E., \& Gaertner, L., S. (2006). Intergroup threat and outgroups attitudes: a meta-analytic review. Personality and Social Psychology Review, 10(4), 336353.

Schmidt, L., Palminteri, S., Lafargu, G., \& Pessiglione, M. (2010). Splitting motivation: unilateral effects of subliminal incentive. Psychological Science, 21 (7), 977-983.

Sims, J., \& Saarinen, F., T. (1989). Coping with enviromental threat: great plain farmers and the sudden form. Journal Annals of the Association of American Geographass, 59(4), 677688.

Singh, K., A., \& Narain, V. (2017). A fine muddle: (Re) Configuring water conflicts ? Geoforum, 85, 9-II. 
Subarkah \& Wicaksono, A. (2017) Perlawanan masyarakat samin atas kebijakan pembangunan semen Gresik di Sukolilo Pati: Studi kebijakan berbasis lingkungan dan kearifan lokal. (The Samin society's resistance to semen Gresik's development policy in Sukolilo Pati: environmental and local wisdom-based policy study.). Publication Manuscript. Retrieved from http://unikal.ac.id/journal/index.php/lppm/article/view/3 I I/244.

Suharko. (2013). Karst: Ditambang atau dilestarikan konflik sosial rencana pembangunan pabrik semen di Kabupaten Pati Jawa Tengah. (Karst: Mined or preserved social conflict plans for the construction of a cement factory in Pati Regency, Central Java). Jurnal Ilmu Sosial dan IImu Politik, 17, 163-179. Retrieved from http://journal.ugm.ac.id/isp/article/view/1088I/8I22.

Suharko. (2016). Masyarakat adat versus korporasi: Konflik sosial rencana pembangunan pabrik semen di Kabupaten Pati Jawa Tengah periode 2013-2016. (Indigenous people versus corporations: Social conflict plans to build a cement plant in Pati, Central Java, 20I3-20I6). Jurnal IImu Sosial dan Ilmu Politik, 20(2), 97-I/6.Retrieved from http://journal.ugm.ac.id/jpap/article/view/24776/16027.

Suyono, H. (2013). Studi kualitatif menemukan indikator konflik lahan pantai kulon progo. (The qualitative study found indicators of Kulon Progo beach land conflict). Unpublished Manuscript. Yogyakarta: Lembaga Penelitian dan Pengabdian Masyarakat Universitas Ahmad Dahlan.

Suyono, H. (2015). Pengembangan model dan indeks deteksi dini konflik dengan predictor identitas sosial, prasangka, dan intensi. (Development of models and indices of conflict early detection with social identity predictors, prejudices and intentions). Unpublished doctoral dissertation. Surabaya: Fakultas Psikologi UniversitasAirlangga.

Tajfel, H., \& Turner, C., J. (2004). The social identity theory of intergroup behavior. Edited by Jost\&Sidanus (Political Psychology). New York: Psychology Pers.

Zarate, A., M., Garcia, B., Garza, A., A., \& Hitlan, T., R. (2004). Cultural threat and perceived realistic group conflict as dual predictors prejudice. Journal of Experimental Social Psychology, 40, 99-105. 